\title{
Effect of different fat supplements on the antioxidant capacity of cow's milk
}

Kamila Puppel, Teresa Nałęcz-Tarwacka, Beata Kuczyńska, Marcin Gołębiewski and Marta Kordyasz

Cattle Breeding Division, Department of Animal Breeding, Warsaw University of Life Sciences, Warsaw, Poland

\section{Abstract}

This study examined the effect of different fat supplements on the antioxidants of cow's milk. Thirty five Polish Holstein Friesian cows at $180 \pm 20$ day of lactation and averaging $17.71 \pm 2.26 \mathrm{~kg} / \mathrm{d}$ of milk were divided into five equal groups. There were five treatments groups: $300 \mathrm{~g} / \mathrm{d}$ of fish oil, $500 \mathrm{~g} / \mathrm{d}$ of Opal linseed, $500 \mathrm{~g} / \mathrm{d}$ of Szafir linseed, $150 \mathrm{~g} / \mathrm{d}$ of fish oil + $250 \mathrm{~g} / \mathrm{d}$ of Opal linseed, $150 \mathrm{~g} / \mathrm{d}$ of fish oil $+250 \mathrm{~g} / \mathrm{d}$ Szafir linseed. Milk samples were collected five times during the 21 day of supplementation period: at the 1st, 14th and 21th day of the experimental period, and also at the 14th and 21st day after the supplement withdrawal. Diet supplementation with the Szafir linseed improved the chemical composition and milk yield at the 21st day of experiment. The highest level of malondialdehyde was recorded in fish oil, Opal linseed, fish oil + Opal linseed, and fish oil + Szafir linseed groups, and the lowest in the Szafir linseed group. After the 21st day of supplementation the concentration of a-retinol was significantly increased in all groups by 23 to $183 \%$. The highest level of a-tocopherol was found in fish oil + Opal linseed group at the 21st day of supplementation. Total antioxidative status increased in all experimental groups; however, the highest peak was recorded in fish oil + Szafir linseed and Szafir linseed group. The experiment confirmed that manipulation in cows' diet may improve antioxidative capacity of milk.

Keywords: fish oil, linseed, antioxidant, cow, milk composition
Abbreviations: CTL: controldiet, DM: dry matter, DMI: dry matter intake, FFA: free fatty acids, FO: fish oil, FOO: fish oil + Opal linseed, FOS: fish oil + Szafir linseed, INRA: National Institute for Agricultural Research (France), MDA: malondialdehyde, LO: Opal linseed, LS: Szafir linseed, SCC: somatic cell count, TAS: total antioxidant status, TMR: total mixed ration

Archiv Tierzucht 56 (2013) 17, 178-190

doi: 10.7482/0003-9438-56-017

Corresponding author:

Marcin Gołębiewski; email: marcin_golebiewski@sggw.pl

Warsaw University of Life Sciences, Nowoursynowska 166, 02-78 Warsaw, Poland
Received: 12 March 2012

Accepted: 4 July 2012

Online: 8 March 2013

() 2013 by the authors; licensee Leibniz Institute for Farm Animal Biology (FBN), Dummerstorf, Germany.

This is an Open Access article distributed under the terms and conditions of the Creative Commons Attribution 3.0 License (http://creativecommons.org/licenses/by/3.0/). 


\section{Introduction}

Recent studies suggest that free radicals have been implicated in the development of over 100 diseases affecting all major organs. Reactive oxygen species are chemically reactive molecules containing oxygen. Antioxidants help to defend the body against free radicals.

One of the most important indicators of oxidation process in milk is malondialdehyde (MDA), which is formed during peroxidation of polyunsaturated fatty acids by the action of reactive oxygen species. Increasing level of MDA modifies the physical properties of the cell membrane, resulting in depletion of antioxidant systems. Mutagenic and carcinogenic properties of reactive oxygen species have also been confirmed by Chen et al. (2000).

Nevertheless, cow's milk contains a range of biologically active substances with antioxidant properties, which reduce the risk of arteriosclerosis and protect against heart disease, reduce the risk of cancer, slow down the progress of Alzheimer's disease, protect the body against environmental pollutants. The typical exogenous antioxidants supplied with food or as supplements are selected vitamins ( $A, C, E)$, carotenoids ( $\alpha$ - and $\beta$-carotene) and also exogenous coenzyme Q10. Beta-carotene (provitamin of vitamin A) reduces the risk of breast, lung, stomach and uterus cancer and provides protection against the onset of myocardial infarction and stroke (O'Grady et al. 2001). Rice-Evans et al. (1997) showed that carotenoids exhibit antioxidant properties, including free radicals as a result of transfer of free electrons, or by creating adducts with them. In addition, a-retinol traps peroxyl radicals, and $\beta$-carotene singlet oxygen. Vitamin $E$ is one of the most important antioxidants in milk. It prevents lipid peroxidation through the capture of singlet oxygen and hydroxyl radicals (Kamal-Eldin \& Appelquist 1996). Palozza et al. (2000), examining the effect of C20:5 n-3 (EPA)and $\beta$-carotene on the growth of tumour cells, also confirmed the role of peroxidation products in this process. According to Gonzalez et al. (1993), in mice implanted with human breast cancer, fed with corn oil or its mixtures with different amounts of fish oil, tumour growth was inhibited when fed with addition of fish oil. Naziroglu et al. (2004) states that vitamin E supplementation decreases the concentration of MDA in the liver of rats. The purpose of this study was to improve the quality of milk fat affecting the health of consumers by elevating antioxidants level in cow's milk. Increasing of the antioxidant capacity of milk by the use of food supplements is a simple method of its modification, which can be advantageous both for the consumers and for the technological quality of milk. There are many studies, in which various forms (whole, rolled, crushed or ground) and quantities of linseeds were analysed as supplements affecting quality of milk (Allred et al. 2006, Nałęcz-Tarwacka et al. 2008, Chilard et al. 2009). Nevertheless, no studies have been conducted to investigate the impact of linseeds variety on the level of fat soluble vitamins, $\beta$-carotene and the overall antioxidant effect of milk in one experiment. Also, combined supplementation of fish oil and linseeds is a new solution. Comparison of five different fatty additives in a nutritional experiment allows for selection of the type of supplement, preferably affecting the changes in the content of vitamins soluble in fat and in the overall antioxidant capacity of cow's milk. The purpose of this study was to improve the quality of milk fat affecting the health of consumers by elevating antioxidants level in cow's milk. Obtaining a greater antioxidant capacity of milk by the use of feed supplements is a simple method of its modification, which can be advantageous both for consumers and for the technological quality of milk. 


\section{Material and methods}

The experiment was conducted at experimental dairy farm belonged to Warsaw University of Life Sciences in Poland. All cows were handled in accordance with the Polish Council on Animal Care regulations. The Warsaw University of Life Sciences Care Committee reviewed and approved the experiment and all procedures carried out in the study.

\section{Animals, treatment, and sampling}

Thirty five Polish Holstein Friesian cows, 15 primiparous and 20 multiparous (at second and third lactation) at $180 \pm 20$ day of lactation and averaging $17.71 \pm 2.26 \mathrm{~kg} / \mathrm{d}$ of milk were divided into five equal groups. The treatments were:

1) $\mathrm{FO}=$ control with $300 \mathrm{~g} / \mathrm{d}$ fish oil,

2) $L O=$ control with $500 \mathrm{~g} / \mathrm{d}$ linseed Opal variety,

3) $\mathrm{LS}=$ control with $500 \mathrm{~g} / \mathrm{d}$ linseed Szafir variety,

4) $\mathrm{FOO}=$ control with $150 \mathrm{~g} / \mathrm{d}$ fish oil $+250 \mathrm{~g} / \mathrm{d}$ linseed Opal varieties,

5) $\mathrm{FOS}=$ control with $150 \mathrm{~g} / \mathrm{d}$ fish oil $+250 \mathrm{~g} / \mathrm{d}$ linseed Szafir varieties.

Milk collected before the supplementation period (collecting 1 ) was the reference to further supplementation changes. Crude linseed was given as unprocessed whole seeds. During the first seven days of experiment cows were customized to new supplements in diet. The supplements were administered individually into each animal's feeder every day at the same time (in the morning) for 21 days. Fish oil used in the experiment was manufactured during fish meal production process of the following fish: herring, sprat, silver carp, mackerel and cod, and was purchased in the Agro-Fish company. During the storage the oil was stabilized with antioxidant Randox (Randox, Crumlin, UK), enriched in a-tocopherol $(20.04 \mathrm{mg} / 100 \mathrm{~g}$ of oil). The two varieties of linseed, Opal and Szafir, were used in the experiment.

During the experiment the five feeding places were separated in frees stall barn, so that each cow had free access to the trough with supplements. Throughout the experiment, no cases of failure to eat the entire amount of the administered supplements were observed.

The cows were milked daily at 05.30 and 17.30 and milk yield was recorded at each milking. Milk samples were collected five times: at the 1st day of supplementing period (collecting 1) after the 14th (collecting 2) and 21st day of the supplementation period (collecting 3 ) as well as 14th (collecting 4) and 21th (collecting 5) day after experimental period. Representative milk samples were collected from each cow individually during milking by means of a milk meter in the milking parlour. Combined milk from morning and evening milking were placed in sterile bottles, preserved with Mlekostat CC (Zekar, Brwinów, Poland). The samples were immediately submitted to the Cattle Breeding Division (Milk Testing Laboratory of Warsaw University of Life Sciences) for compositional analysis immediately after milking.

The cows were kept in a free-stall dairy shed and fed on total mixed ration (TMR) diet. All animals had continuous access to water. TMR diet was provided for ad libitum intake, dry matter intake (DMI) was monitored daily throughout the experiment. Cows were fed TMR two times a day at 8.00 and 18.00. The TMR diets were formulated using the French National Institute for Agricultural Research (INRA) system to provide adequate milk energy and milk production for a $650-\mathrm{kg}$ cow producing $20 \mathrm{~kg}$ of milk/d containing $3.5 \%$ fat and $3.2 \%$ protein. Representative TMR samples were pooled three times per three week and 
stored at $-20^{\circ} \mathrm{C}$ until analysis. Samples were analysed in Cattle Breeding Division (Poland) for dry matter (DM), crude protein, ash, ether extract, acid detergent fibre, neutral detergent fibre. The chemical composition of the TMR was calculated from the chemical composition of individual ingredients of the diet. Daily DMI for individual cows was calculated by subtracting the weekly mean of orts from the weekly mean of feed offered. According to INRA diet offered to cows faced their requirements $( \pm 5 \%)$. Chemical composition of the treatment diets is presented in the Table 1.

Table 1

Ingredients and chemical composition of control diet (CTL)

\begin{tabular}{lc}
\hline Composition & TMR diet \\
\hline Ingredient, kg/d & 26.0 \\
Maize corn silage & 9.40 \\
Alfalfa silage & 3.50 \\
Corn silage & 1.10 \\
Soybean meal & 0.10 \\
Pasture ground chalk & 0.16 \\
Vitosa vitamin mix ${ }^{1}$ & 0.05 \\
Salt & 2.20 \\
Rapeseed meal & 0.05 \\
Magnesium oxide & 0.00 \\
Bolifor Mg mineral mix, kg/d ${ }^{2}$ & \\
Chemical composition & 58.5 \\
DM,\% & 18.6 \\
Crude protein, \% of DM & 19.6 \\
Acid detergent fiber, \% of DM & 29.1 \\
Neutral detergent fiber, \% of DM & 4.5 \\
Ash, \% of DM & 4.6 \\
Ether extract, \% of DM & 0.8 \\
Ca,\% of DM & 0.4 \\
P,\% of DM & 18.2 \\
Total (UFL) & 1749 \\
Total (PDIE), g & 1735 \\
Total (PDIN), g & \\
\hline
\end{tabular}

${ }^{1}$ Contained (on 1000 g): Ca 150 g, P 100 g, Na 50 g, Mg 40 g, Zn 9000 mg, Mn 7000 mg, Cu 1000 mg, J 100 mg, Se 50 mg, vitamin A 1200000 j.m., vitamin D3 120000 j.m., vitamin E $5000 \mathrm{mg}$, vitamin K $93 \mathrm{mg}$, vitamin B1 $80 \mathrm{mg}$, vitamin B6 $160 \mathrm{mg}$, vitamin B2 $110 \mathrm{mg}$, vitamin B12 $1000 \mathrm{mcg}$, ${ }^{2}$ Contained (on $1000 \mathrm{~g}$ ): Mg 24\%, P 13.5\%, Ca 1\%

\section{Chemical analyses}

Basic parameters of the milk, i.e. fat, protein, casein, lactose and free fatty acid content were determined by automated infrared analysis with a MilkoScan FT120 instrument (Foss, Hillerød, Denmark).

Evaluation of hygienic status of the milk was based on somatic cell count on Somacount 150 (Bentley Instruments, Inc., Chaska, MI, USA)).

MDA were determined spectrophotometrically according Mroczek (1967).

For examination of the fatty acid composition the fat from the treatment and supplements, were extracted according to Rose-Gottlieb procedure (AOAC 1990) at room temperature. Fatty acid methylation was performed according to the trans esterification method by Kramer et 
al. (1998). Identification of the individual fatty acids was carried out by gas chromatography using Hewlett Packard 6890 GC with HP Chem software (Hewlett Packard, Palo Alto, CA, USA), a flame-ionization detector, and a Varian Select FAME column (Agilent Technologies, Santa Clara, CA, USA); $100 \mathrm{~m}$ length, $0.25 \mathrm{~mm}$ in diameter and $0.25 \mu \mathrm{m}$ thick. The separation was performed at pre-programmed temperature: $130^{\circ} \mathrm{C}$ for $1 \mathrm{~min} ; 130-170^{\circ} \mathrm{C}$ at $6.5 \mathrm{~min}$; 170 $215^{\circ} \mathrm{C}$ at $2.75 \mathrm{~min} ; 215^{\circ} \mathrm{C}$ for $12 \mathrm{~min}, 215-230^{\circ} \mathrm{C}$ at $20 \mathrm{~min}$ and $230^{\circ} \mathrm{C}$ for $3 \mathrm{~min}$. Helium at a flow rate of $25 \mathrm{~cm} / \mathrm{s}$ and constant pressure was used as the carrier gas, the injector temperature was $240^{\circ} \mathrm{C}$, and the detector temperature was $300^{\circ} \mathrm{C}$.

Separations of vitamins soluble in fat: $\mathrm{A}-\alpha$-retinol, $\mathrm{E}$ - $\alpha$-tocopherol and $\beta$-carotene, were performed at ambient temperature, using $4.6 \times 150 \mathrm{~mm}, 5 \mu \mathrm{m}$ Zorbax Eclipse XDB C 8 column (Puppel 2011). Solvent flow rate was maintained at $1.2 \mathrm{ml} / \mathrm{min}$, an isocratic elution of $90 / 10$ (vol./vol.) methanol to water. Eluate from the column was monitored at $280 \mathrm{~nm}$ by Agilent UV detector (Agilent Technologies, Santa Clara, CA, USA). Quantitative analysis was performed, using peak area measurement and standard curve.

The determination of the antioxidant components was performed using a Randox-TAS (total antioxidant status) test, according to the application described by Randox and Puppel (2011).

\section{Statistical analysis}

The obtained data were analysed statistically using a multi-factor analysis of variance (least squares) by means of the SPSS 12.0 packet software (SPSS Inc., Chicago, IL, USA). Only statistically significant $(P \leq 0.01$ or $P \leq 0.05)$ interactions between factors were considered in the study. The level of significance was determined after performing preliminary statistical analyses.

The model used for analysed milk samples was:

$$
Y_{i j k}=\mu+A_{i}+B_{j}+\left(A_{i} \times B_{j}\right)+e_{i j k}
$$

where $Y_{i j k}$ is the dependent variable, $A_{i}$ is the treatment effect ( $i=1-6 ; 1$ : control; 2: FO; 3: LO; 4: LS; 5: FOO; 6: FOS), $B_{j}$ is the collecting effect $(j=1-5), A_{i} \times B_{j}$ is the fixed interaction effect between treatment and collecting and $e_{i j k l}$ is the random error.

\section{Results}

Chemical composition of the TMR is presented in the Table 1 , and the content of fatty acids in the supplements in Table 2. Linseeds were an excellent source of $C_{18: 2}$ cis-9, $C_{18: 2} n-6$ and $C_{18: 3}$ $\mathrm{n}-3$. Opal variety was characterized by higher content of $C_{18: 2}$ cis-9 and $C_{18: 2} n-6$, but Szafir variety was the richest source of $\mathrm{C}_{18: 3} \mathrm{n}-3$ and $\mathrm{C}_{16: 1}$ acid (Table 2).

The effect of lipid supplementation on the level of fat in milk is well understood, but it should be noted that the obtained results were very diverse. A statistically significant reduction in milk fat content in four groups: FO, LO, FOO, FOS was recorded (Table 3).

As for the total protein content, was a statistically significant increase in its level in milk was recorded after using the following supplements: FO, LO, LS and FOS (Table 3). The fat supplements applied affected slightly the concentration of lactose and SCC levels during the experimental period (Table 3). The addition of $L S$ improved chemical composition and milk yield after the 21st day. Supplementation of LS influenced most preferably the chemical composition of cow's milk; the study has shown increase in the percentage of protein, fat and lactose. 
Table 2

Fatty acid composition of the treatment diets: TMR, fish oil and linseed ( $\mathrm{g} / 100 \mathrm{~g}$ of fatty acid)

\begin{tabular}{lcccc}
\hline Fatty acid & TMR $(C T L)$ & Fish oil & Opal & Sariety of linseed \\
\hline$C_{14: 0}$ & & 5.02 & 0.03 & 0.09 \\
$C_{14: 1}$ & 1.80 & 0.22 & 0.02 & 0.01 \\
$C_{16: 0}$ & 0.84 & 18.00 & 5.51 & 6.46 \\
$C_{16: 1}$ & 27.5 & 6.02 & 0.08 & 0.11 \\
$C_{18: 0}$ & 0.18 & 0.31 & 4.81 & 4.87 \\
$C_{18: 1}$ cis-9 & 18.91 & 24.90 & 21.83 & 15.26 \\
$C_{18: 2}^{n} n-6$ & 24.67 & 4.32 & 14.34 & 11.58 \\
$C_{18: 3} n-3$ & 3.7 & 2.90 & 51.70 & 59.42 \\
$C_{20: 5} n-3$ & 1.87 & 0.40 & 0.00 & 0.00 \\
$C_{22: 5} n-3$ & 0.032 & 0.80 & 0.00 & 0.00 \\
$C_{22: 6} n-3$ & 0.03 & 12.66 & 0.00 & 0.00 \\
\hline
\end{tabular}

Table 3

Influence of supplementation on milk yield, the basic composition of milk and SCC

\begin{tabular}{|c|c|c|c|c|c|c|c|c|c|c|c|}
\hline \multirow[t]{2}{*}{ Supplements } & \multirow[t]{2}{*}{ Collecting } & \multicolumn{2}{|c|}{$\begin{array}{c}\text { Milk yield, } \\
\text { kg/d }\end{array}$} & \multicolumn{2}{|c|}{$\begin{array}{c}\text { Protein, } \\
\%\end{array}$} & \multicolumn{2}{|c|}{$\begin{array}{c}\text { Fat, } \\
\%\end{array}$} & \multicolumn{2}{|c|}{$\begin{array}{l}\text { Lactose, } \\
\%\end{array}$} & \multicolumn{2}{|c|}{$\begin{array}{c}\text { SCC, } \\
\text { tys. } / \mathrm{cm}^{3}\end{array}$} \\
\hline & & LSM & SE & LSM & SE & LSM & SE & LSM & SE & LSM & SE \\
\hline \multirow[t]{5}{*}{ FO } & $1 \mathrm{CTL}$ & 15.08 & 0.328 & $3.71^{A B C}$ & 0.079 & $4.35^{A B}$ & 0.154 & 4.89 & 0.034 & 125 & 31.971 \\
\hline & 2 & 15.32 & 0.569 & $3.70^{\mathrm{D}}$ & 0.137 & $3.37^{\mathrm{ACDE}}$ & 0.267 & 4.94 & 0.058 & 182 & 55.375 \\
\hline & 3 & 13.56 & 0.569 & $3.81^{A D E}$ & 0.137 & $3.47^{\mathrm{BCFG}}$ & 0.267 & 4.86 & 0.058 & 271 & 55.375 \\
\hline & 4 & 16.64 & 0.569 & $3.81^{\mathrm{BF}}$ & 0.137 & $4.27^{\mathrm{DF}}$ & 0.267 & 5.00 & 0.058 & 94 & 55.375 \\
\hline & 5 & 15.84 & 0.569 & $3.89^{\mathrm{CEF}}$ & 0.137 & $4.49^{\mathrm{EG}}$ & 0.267 & 4.94 & 0.058 & 115 & 55.375 \\
\hline \multirow[t]{5}{*}{ LO } & $1 \mathrm{CTL}$ & 15.08 & 0.328 & $3.71^{A B C}$ & 0.079 & $4.35^{A B}$ & 0.154 & 4.89 & 0.034 & 125 & 31.971 \\
\hline & 2 & 14.90 & 0.569 & $3.77^{\mathrm{D}}$ & 0.137 & $4.04^{A C D E}$ & 0.267 & 4.80 & 0.058 & 149 & 55.375 \\
\hline & 3 & 13.20 & 0.569 & $3.78^{\mathrm{ADE}}$ & 0.137 & $3.76^{\mathrm{BcFG}}$ & 0.267 & 4.82 & 0.058 & 76 & 55.375 \\
\hline & 4 & 12.80 & 0.569 & $3.80^{\mathrm{BF}}$ & 0.137 & $4.47^{D F}$ & 0.267 & 4.85 & 0.058 & 102 & 55.375 \\
\hline & 5 & 12.40 & 0.569 & $3.88^{\mathrm{CEF}}$ & 0.137 & $4.62^{\mathrm{EG}}$ & 0.267 & 4.83 & 0.058 & 94 & 55.375 \\
\hline \multirow[t]{5}{*}{ LS } & $1 \mathrm{CTL}$ & 15.08 & 0.328 & $3.71^{A B C}$ & 0.079 & $4.35^{\mathrm{AB}}$ & 0.154 & 4.89 & 0.034 & 125 & 31.971 \\
\hline & 2 & 18.80 & 0.569 & $3.87^{D}$ & 0.137 & $4.62^{A C D E}$ & 0.267 & 4.88 & 0.058 & 171 & 55.375 \\
\hline & 3 & 17.10 & 0.569 & $3.89^{A D E}$ & 0.137 & $4.50^{\mathrm{BCFG}}$ & 0.267 & 4.91 & 0.058 & 86 & 55.375 \\
\hline & 4 & 16.26 & 0.569 & $3.96^{\mathrm{BF}}$ & 0.137 & $5.44^{\mathrm{DF}}$ & 0.267 & 5.00 & 0.058 & 85 & 55.375 \\
\hline & 5 & 17.80 & 0.569 & $4.05^{\mathrm{CEF}}$ & 0.137 & $5.41^{\mathrm{EG}}$ & 0.267 & 5.00 & 0.058 & 93 & 55.375 \\
\hline \multirow[t]{5}{*}{ FOO } & $1 \mathrm{CTL}$ & 15.08 & 0.328 & $3.71^{A B C}$ & 0.079 & $4.35^{A B}$ & 0.154 & 4.89 & 0.034 & 125 & 31.971 \\
\hline & 2 & 18.52 & 0.569 & $3.50^{\mathrm{D}}$ & 0.137 & $3.75^{\mathrm{AcDE}}$ & 0.267 & 4.89 & 0.058 & 48 & 55.375 \\
\hline & 3 & 17.44 & 0.569 & $3.52^{\mathrm{ADE}}$ & 0.137 & $3.36^{\mathrm{BCFG}}$ & 0.267 & 4.88 & 0.058 & 49 & 55.375 \\
\hline & 4 & 17.20 & 0.569 & $3.57^{\mathrm{BF}}$ & 0.137 & $4.19^{\mathrm{DF}}$ & 0.267 & 4.94 & 0.058 & 89 & 55.375 \\
\hline & 5 & 20.0 & 0.569 & $3.88^{\mathrm{CEF}}$ & 0.137 & $4.46^{\mathrm{EG}}$ & 0.267 & 4.88 & 0.058 & 112 & 55.375 \\
\hline \multirow[t]{5}{*}{ FOS } & $1 \mathrm{CTL}$ & 15.08 & 0.328 & $3.71^{A B C}$ & 0.079 & $4.35^{A B}$ & 0.154 & 4.89 & 0.034 & 125 & 31.971 \\
\hline & 2 & 16.32 & 0.569 & $3.65^{\mathrm{D}}$ & 0.137 & $3.86^{\mathrm{ACDE}}$ & 0.267 & 5.04 & 0.058 & 148 & 55.375 \\
\hline & 3 & 15.15 & 0.569 & $3.85^{A D E}$ & 0.137 & $3.85^{\mathrm{BcFG}}$ & 0.267 & 5.02 & 0.058 & 166 & 55.375 \\
\hline & 4 & 18.06 & 0.569 & $3.82^{\mathrm{BF}}$ & 0.137 & $4.08^{\mathrm{DF}}$ & 0.267 & 5.09 & 0.058 & 198 & 55.375 \\
\hline & 5 & 16.72 & 0.569 & $3.81^{\mathrm{CEF}}$ & 0.137 & $4.80^{\mathrm{EG}}$ & 0.267 & 5.04 & 0.058 & 217 & 55.375 \\
\hline
\end{tabular}

A-G $P \leq 0.01$, a-g $P \leq 0.05$, FO: control with $300 \mathrm{~g} / \mathrm{dfish}$ oil, LO: control with $500 \mathrm{~g} / \mathrm{d}$ linseed of Opal variety, LS: control with $500 \mathrm{~g} / \mathrm{d}$ linseed of Szafir variety, FOO: control with $150 \mathrm{~g} / \mathrm{d}$ fish oil and $250 \mathrm{~g} / \mathrm{d}$ linseed of Opal varieties, FOS: control with $150 \mathrm{~g} / \mathrm{d}$ fish oil and $250 \mathrm{~g} / \mathrm{d}$ linseed of Szafir varieties, 1: at the first day of supplementing period, 2: at the 14th day of supplementing period, 3: at the 21st day of the supplementation period, 4: at the 14th after supplementing period, 5: at the 21th after supplementing period 
The TBA test (thiobarbituric acid) provides information about the level of MDA, a secondary compound formed in lipid oxidation. In all groups, a significant increase of MDA concentration in milk was noted (Table 4) after the 21st day of supplementation. The highest level of MDA was recorded in four groups: FO, LO, FOO and FOS. The lowest MDA content was noted in the LS group $(0.378 \mathrm{mg} / \mathrm{l}$ of milk), which resulted in an increased concentration of this component by $34 \%$ compared to the first collection (Table 4). One of the main enzymatic reactions causing quality deterioration in raw milk is lipolysis. Lipolysis is the breakdown of triglycerides to free fatty acids (FFA). During the 21st day supplementation period, a very significant increase in FFA content in all dietary groups was found (Table 4). The highest level of FFA was observed in the group with the combined supplementation of fish oil and linseed: FOO and FOS. On the other hand, the lowest level was recorded in LS group $-0.520 \mathrm{~g} / 100 \mathrm{~g}$ of fat.

Table 4

Influence of supplementation on the MDA ( $\mathrm{mg} / \mathrm{l}$ of milk) and FFA ( $\mathrm{g} / 100 \mathrm{~g}$ of fat) content

\begin{tabular}{|c|c|c|c|c|c|}
\hline \multirow[t]{2}{*}{ Supplements } & \multirow[t]{2}{*}{ Collecting } & \multicolumn{2}{|c|}{ MDA } & \multicolumn{2}{|c|}{ FFA } \\
\hline & & LSM & SE & LSM & SE \\
\hline \multirow[t]{5}{*}{ FO } & $1 \mathrm{CTL}$ & $0.282^{A B}$ & 0.028 & $0.412^{A B C}$ & 0.035 \\
\hline & 2 & $0.471^{A C D E}$ & 0.049 & $0.325^{\text {ADEf }}$ & 0.061 \\
\hline & 3 & $0.707^{B C F G}$ & 0.049 & $0.613^{\mathrm{BDGH}}$ & 0.061 \\
\hline & 4 & $0.191^{\mathrm{DF}}$ & 0.049 & $0.232^{\mathrm{CEGi}}$ & 0.061 \\
\hline & 5 & $0.165^{\mathrm{EG}}$ & 0.049 & $0.356^{\mathrm{fHi}}$ & 0.061 \\
\hline \multirow[t]{5}{*}{ LO } & $1 \mathrm{CTL}$ & $0.282^{\mathrm{AB}}$ & 0.028 & $0.412^{A B C}$ & 0.035 \\
\hline & 2 & $0.462^{A C D E}$ & 0.049 & $0.320^{\text {ADEf }}$ & 0.061 \\
\hline & 3 & $0.687^{\mathrm{BCFG}}$ & 0.049 & $0.550^{\mathrm{BDGH}}$ & 0.061 \\
\hline & 4 & $0.381^{\mathrm{DF}}$ & 0.049 & $0.350^{\mathrm{CEGi}}$ & 0.061 \\
\hline & 5 & $0.355^{\mathrm{EG}}$ & 0.049 & $0.352^{\mathrm{fHi}}$ & 0.061 \\
\hline \multirow[t]{5}{*}{ LS } & $1 \mathrm{CTL}$ & $0.282^{\mathrm{AB}}$ & 0.028 & $0.412^{\mathrm{ABC}}$ & 0.035 \\
\hline & 2 & $0.433^{\mathrm{ACDE}}$ & 0.049 & $0.350^{\text {ADEf }}$ & 0.061 \\
\hline & 3 & $0.378^{\text {BCFG }}$ & 0.049 & $0.520^{\mathrm{BDGH}}$ & 0.061 \\
\hline & 4 & $0.189^{\mathrm{DF}}$ & 0.049 & $0.373^{\mathrm{CEGi}}$ & 0.061 \\
\hline & 5 & $0.182^{\mathrm{EG}}$ & 0.049 & $0.400^{\mathrm{fHi}}$ & 0.061 \\
\hline \multirow[t]{5}{*}{ FOO } & $1 \mathrm{CTL}$ & $0.282^{\mathrm{AB}}$ & 0.028 & $0.412^{A B C}$ & 0.035 \\
\hline & 2 & $0.452^{\mathrm{ACDE}}$ & 0.049 & $0.344^{\mathrm{ADEf}}$ & 0.061 \\
\hline & 3 & $0.677^{B C F G}$ & 0.049 & $0.635^{\mathrm{BDGH}}$ & 0.061 \\
\hline & 4 & $0.181^{\mathrm{DF}}$ & 0.049 & $0.352^{\mathrm{CEGi}}$ & 0.061 \\
\hline & 5 & $0.165^{\mathrm{EG}}$ & 0.049 & $0.400^{\mathrm{fHi}}$ & 0.061 \\
\hline \multirow[t]{5}{*}{ FOS } & $1 \mathrm{CTL}$ & $0.282^{\mathrm{AB}}$ & 0.028 & $0.412^{\mathrm{ABC}}$ & 0.035 \\
\hline & 2 & $0.463^{\mathrm{ACDE}}$ & 0.049 & $0.346^{\text {ADEf }}$ & 0.061 \\
\hline & 3 & $0.758^{\mathrm{BCFG}}$ & 0.049 & $0.622^{\mathrm{BDGH}}$ & 0.061 \\
\hline & 4 & $0.249^{\mathrm{DF}}$ & 0.049 & $0.311^{\mathrm{CEGi}}$ & 0.061 \\
\hline & 5 & $0.232^{\mathrm{EG}}$ & 0.049 & $0.382^{\mathrm{fHi}}$ & 0.061 \\
\hline
\end{tabular}

${ }^{A-J} P \leq 0.01,{ }^{\mathrm{a}-\mathrm{j}} P \leq 0.05, \mathrm{FO}$ : control with $300 \mathrm{~g} / \mathrm{dfish}$ oil, $L \mathrm{LO}$ : control with $500 \mathrm{~g} / \mathrm{d}$ linseed of Opal variety, LS: control with $500 \mathrm{~g} / \mathrm{d}$ linseed of Szafir variety, FOO: control with $150 \mathrm{~g} / \mathrm{d}$ fish oil and $250 \mathrm{~g} / \mathrm{d}$ linseed of Opal varieties, FOS: control with $150 \mathrm{~g} / \mathrm{d}$ fish oil and $250 \mathrm{~g} / \mathrm{d}$ linseed of Szafir varieties, 1 : at the first day of supplementing period, 2: at the 14th day of supplementing period, 3: at the 21st day of the supplementation period, 4: at the 14th after supplementing period, 5: at the 21th after supplementing period

The effect of supplementation on the content of selected antioxidants and TAS was presented in the Table 5. Applied fatty additives significantly influenced both the content of soluble vitamins fat and antioxidant properties of milk. $\beta$-carotene content at 21st day 
of supplementing increased significantly in the following groups: FO (by $64.88 \%$ ), LO (by $70.92 \%$ ), LS (by $69.80 \%$ ), FOO (by $46.31 \%$ ) and FOS (by 7.16\%). The highest content was noted in the LO group $(0.764 \mathrm{mg} / \mathrm{l})$. Formation of $\beta$-carotene in milk after 21 days of supplementation was as follows: $\mathrm{LO}>\mathrm{LS}>\mathrm{FO}>\mathrm{FOO}>\mathrm{FOS}$.

Table 5

Influence of supplementation on the Vitamin soluble in fat ( $\mathrm{mg} / \mathrm{l})$ content and TAS ( $\mathrm{mmol} / \mathrm{l})$

\begin{tabular}{|c|c|c|c|c|c|c|c|c|c|}
\hline \multirow[t]{2}{*}{ Supplemets } & \multirow[t]{2}{*}{ Collecting } & \multicolumn{2}{|c|}{$\beta$-caroten } & \multicolumn{2}{|c|}{ Vitamin A } & \multicolumn{2}{|c|}{ Vitamin E } & \multicolumn{2}{|c|}{ TAS } \\
\hline & & LSM & SE & LSM & SE & LSM & SE & LSM & SE \\
\hline \multirow[t]{5}{*}{ FO } & $1 \mathrm{CTL}$ & $0.447^{a b c}$ & 0.050 & $0.728^{\mathrm{ABC}}$ & 0.138 & $1.200^{A B C}$ & 0.147 & $1.282^{\mathrm{ABCD}}$ & 0.087 \\
\hline & 2 & 0.538 & 0.086 & $1.154^{\mathrm{A}}$ & 0.239 & $1.125^{\mathrm{D}}$ & 0.254 & $2.359^{\mathrm{AEFG}}$ & 0.150 \\
\hline & 3 & $0.737^{\mathrm{a}}$ & 0.086 & $1.624^{B}$ & 0.239 & $1.739^{\text {BDef }}$ & 0.254 & $2.368^{\mathrm{BEHi}}$ & 0.150 \\
\hline & 4 & $0.514^{b}$ & 0.086 & 1.331 & 0.239 & $1.237^{\mathrm{e}}$ & 0.254 & $2.704^{\mathrm{CFHj}}$ & 0.150 \\
\hline & 5 & $0.600^{c}$ & 0.086 & $0.866^{c}$ & 0.239 & $1.321^{\mathrm{cf}}$ & 0.254 & $2.795^{\mathrm{DGij}}$ & 0.150 \\
\hline \multirow[t]{5}{*}{ LO } & $1 \mathrm{CTL}$ & $0.447^{a b c}$ & 0.050 & $0.728^{A B C}$ & 0.138 & $1.200^{\mathrm{ABC}}$ & 0.147 & $1.282^{\mathrm{ABCD}}$ & 0.087 \\
\hline & 2 & 0.489 & 0.086 & $0.983^{\mathrm{A}}$ & 0.239 & $1.303^{\mathrm{DE}}$ & 0.254 & $2.337^{\mathrm{AEFG}}$ & 0.150 \\
\hline & 3 & $0.764^{\mathrm{a}}$ & 0.086 & $0.898^{B}$ & 0.239 & $1.759^{\mathrm{AFG}}$ & 0.254 & $2.317^{\mathrm{BEHi}}$ & 0.150 \\
\hline & 4 & $0.710^{b}$ & 0.086 & 0.741 & 0.239 & $2.684^{B D F}$ & 0.254 & $3.118^{\mathrm{CFHj}}$ & 0.150 \\
\hline & 5 & $0.656^{c}$ & 0.086 & $1.121^{c}$ & 0.239 & $2.069^{\mathrm{CEG}}$ & 0.254 & $3.185^{\mathrm{DGij}}$ & 0.150 \\
\hline \multirow[t]{5}{*}{ LS } & $1 \mathrm{CTL}$ & $0.447^{a b c}$ & 0.050 & $0.728^{A B C}$ & 0.138 & $1.200^{A B C}$ & 0.147 & $1.282^{A B C D}$ & 0.087 \\
\hline & 2 & 0.794 & 0.086 & $1.636^{\mathrm{A}}$ & 0.239 & $1.842^{\mathrm{AD}}$ & 0.254 & $2.206^{\mathrm{AEFG}}$ & 0.150 \\
\hline & 3 & $0.759^{a}$ & 0.086 & $2.061^{\mathrm{B}}$ & 0.239 & $1.791^{\text {Bef }}$ & 0.254 & $3.131^{\mathrm{BEHi}}$ & 0.150 \\
\hline & 4 & $0.691^{b}$ & 0.086 & 1.605 & 0.239 & $1.406^{\text {cDe }}$ & 0.254 & $2.523^{\mathrm{CFHj}}$ & 0.150 \\
\hline & 5 & $0.800^{C}$ & 0.086 & $1.718^{c}$ & 0.239 & $1.976^{f}$ & 0.254 & $2.982^{\mathrm{DGij}}$ & 0.150 \\
\hline \multirow[t]{5}{*}{ FOO } & $1 \mathrm{CTL}$ & $0.447^{a b c}$ & 0.050 & $0.728^{A B C}$ & 0.138 & $1.200^{\mathrm{ABcd}}$ & 0.147 & $1.282^{\mathrm{ABCD}}$ & 0.087 \\
\hline & 2 & 0.629 & 0.086 & $0.983^{A}$ & 0.239 & $1.703^{A}$ & 0.254 & $2.257^{\mathrm{AEFG}}$ & 0.150 \\
\hline & 3 & $0.654^{\mathrm{a}}$ & 0.086 & $0.978^{B}$ & 0.239 & $1.879^{B}$ & 0.254 & $3.208^{\text {ВЕНi }}$ & 0.150 \\
\hline & 4 & $0.690^{\mathrm{b}}$ & 0.086 & 0.741 & 0.239 & $1.554^{c}$ & 0.254 & $2.365^{\mathrm{CFHj}}$ & 0.150 \\
\hline & 5 & $0.886^{\mathrm{C}}$ & 0.086 & $1.091^{c}$ & 0.239 & $1.889^{d}$ & 0.254 & $2.802^{\mathrm{DGij}}$ & 0.150 \\
\hline \multirow[t]{5}{*}{ FOS } & $1 \mathrm{CTL}$ & $0.447^{a b c}$ & 0.050 & $0.728^{\mathrm{ABC}}$ & 0.138 & $1.200^{\mathrm{ABCD}}$ & 0.147 & $1.282^{\mathrm{ABCD}}$ & 0.087 \\
\hline & 2 & 0.484 & 0.086 & $1.256^{\mathrm{A}}$ & 0.239 & $1.602^{\text {Aef }}$ & 0.254 & $2.246^{\mathrm{AEFG}}$ & 0.150 \\
\hline & 3 & $0.479^{a}$ & 0.086 & $1.161^{\mathrm{B}}$ & 0.239 & $1.641^{\mathrm{Bg}}$ & 0.254 & $3.331^{\text {BEHi }}$ & 0.150 \\
\hline & 4 & $0.511^{b}$ & 0.086 & 0.815 & 0.239 & $1.396^{\mathrm{ceH}}$ & 0.254 & $2.933^{\mathrm{CFHj}}$ & 0.150 \\
\hline & 5 & $0.520^{c}$ & 0.086 & $1.118^{\mathrm{c}}$ & 0.239 & $1.906^{\mathrm{DfgH}}$ & 0.254 & $3.462^{\mathrm{DGij}}$ & 0.150 \\
\hline
\end{tabular}

${ }^{A-J} P \leq 0.01,{ }^{a-j} P \leq 0.05$, FO: control with $300 \mathrm{~g} / \mathrm{dfish}$ oil, LO: control with $500 \mathrm{~g} / \mathrm{d}$ linseed of Opal variety, LS: control with $500 \mathrm{~g} / \mathrm{d}$ linseed of Szafir variety, FOO: control with $150 \mathrm{~g} / \mathrm{d}$ fish oil and $250 \mathrm{~g} / \mathrm{d}$ linseed of Opal varieties, FOS: control with $150 \mathrm{~g} / \mathrm{d}$ fish oil and $250 \mathrm{~g} / \mathrm{d}$ linseed of Szafir varieties, 1: at the first day of supplementing period，2: at the 14th day of supplementing period, 3: at the 21st day of the supplementation period, 4: at the 14th after supplementing period, 5 : at the 21th after supplementing period

Also, the concentration of a-retinol increased significantly in all experimental groups by: 34.34-183.10\%, at 21st day of supplementation. Noteworthy is also a significant increase in vitamin A content in milk of cows receiving the LS supplement (from 0.728 to $2.061 \mathrm{mg} / \mathrm{l}$ ) compared to other groups. Moreover, there was a higher level of a-retinol compared to control collecting in all supplemented groups $(P \leq 0.05)$ at the fifth collecting. Concentration of a-retinol in milk after 21 days of supplementation progressed in accordance with the following scheme: $\mathrm{LS}>\mathrm{FO}>\mathrm{FOS}>\mathrm{FOO}>\mathrm{LO}$.

The use of fatty additives also positively affected the a-tocopherol content. After the 21st day of supplementation, the highest level of a-tocopherol was in FOO group (an increase by $56.58 \%$ ). The lowest level was recorded in FOS group (an increase by $36.75 \%$ ). In the FO, 
LO and LS groups an increase of tocopherol concentration was similar, fluctuating between $44.91 \%$ and $49.25 \%$. A high content of vitamin E was also found after 21 days of administration of supplements (collecting 5) in all of the experimental groups. Amount of a-tocopherol in milk after 21 days of supplementation was changing as follows: $\mathrm{FOO}>\mathrm{LS}>\mathrm{LO}>\mathrm{FO}>\mathrm{FOS}$.

The experiments confirmed a significant increase of TAS in milk in all analysed groups (Table 5). The highest level of TAS was recorded in two groups: FOS, increased from 1.282 to $3.331 \mathrm{mmol} / \mathrm{I}$ (by $159.82 \%$ ) and LS, increased from 1.282 to $3.208 \mathrm{mmol} /$ (by $150.23 \%$ ). In the case of FO, LO and LS, the content of TAS in milk was increased by $84.71 \%, 80.73 \%$ and $144.23 \%$, respectively. During the fifth collecting (after the 21 st day of supplementation), the antioxidant potential of milk was still at a higher level compared to the control collection. The capacity of TAS in milk after 21 days of supplementation was shaped as follows: $\mathrm{FOS}>\mathrm{FOO}>\mathrm{LS}>\mathrm{FO}>\mathrm{LO}$.

\section{Discussion}

Studies conducted over several years show that the introduction of fat supplements (with high concentrations of UFA) in the diet of cows may affect the sensory qualities of milk, through changes in the contents of individual fatty acids (Charmley \& Nicholson 1994). However, already in 1967, King (1967) stated that the addition of $1 \mathrm{~g}$ of tocopherol per day/cow provides excellent protection against these changes. In the experiments conducted, fish oil was stabilized with Randox antioxidant, and it was enriched with tocopherol by $20.04 \mathrm{mg} / 100 \mathrm{~g}$ of oil. Therefore, the dose for cows receiving $300 \mathrm{~g} \mathrm{FO}$ was $60.12 \mathrm{mg}$ tocopherol, whereas in the case of cows receiving $150 \mathrm{~g} \mathrm{FO} \mathrm{-} \mathrm{it} \mathrm{was} \mathrm{lesser} \mathrm{by} \mathrm{half.} \mathrm{Organoleptic} \mathrm{evaluation} \mathrm{of} \mathrm{cow's} \mathrm{milk}$ in experiments did not show sensory changes in analysed milk samples, this relationship is also confirmed by results obtained by authors, such as Nelson \& Martini (2009) and Sympoura et al. (2009), in which the authors showed that the addition of fish oil as a supplement does not affect the sensory quality of milk.

Increased content of $\mathrm{C}_{18: 2} \mathrm{n}-6$ and $\mathrm{C}_{18: 3} \mathrm{n}-3$ fatty acids in milk fat, which is desirable due to its hypocholesterolemic effect, was recognized as an important factor for depressing the oxidative stability of milk fat (Reklewska et al. 2002). Research conducted by Puppel et al. (2012) has shown that combined supplementation of fish oil and linseed has a positive effect on the formation of the levels of these fatty acids in cow's milk; however, the authors do not take into account such factors as the variety of seeds. As it is shown by data on the fatty acid composition of treatment diets (Table 2), the varieties of linseeds were differing in terms of the concentration of individual fatty acids.

According to Doreau et al. (1999), supplementation with fish oil in the amount of 50-100 g/ day/cow may influence the reduced fat concentration in cow's milk. Similar results were also obtained by Bharathan et al. (2008). DePeters \& Cant (1992) indicate that addition of fat reduces the synthesis of protein in the mammary gland (including casein and whey proteins), and therefore may be explained by lower protein content during the supplementing period. The authors explained the reduction of this component by increased stimulation of synthesis of fat and lactose. High fat content reduces blood flow through the mammary gland, thereby reducing the concentration of amino acids. The results of this study did not confirm this phenomenon. The increased total protein content in milk in the experimental groups (FO, LO, 
LS and FOS) was probably the result of additional energy provided in the supplements. The protein content in milk is also associated with the stage of lactation; cows in late lactation are characterized by higher levels of protein, including casein and whey proteins in milk (DePeters \& Taylor 1985). Experimental cows were in the late lactation stage, therefore, characterized by higher concentration of milk protein. Positive influence of fatty supplements on protein content was also confirmed by Bobe et al. (2009) experiment. However, Flowers et al. (2008) found that supplementation of cow diet with flax seeds $(0.17,0.34$ and $0.51 \mathrm{~kg} /$ day $)$ does not influence the performance and content of basic components in the milk protein.

Higher levels of MDA in milk, compared to the results obtained in the experiment carried out by the authors, were showed by Reklewska et al. (2002). Gladine et al. (2007) have demonstrated the protective role of vitamin $E$ in relation to the introduction of PUFA supplementation, and thus demonstrated that tocopherol protects against runaway growth of MDA in milk. Sawosz (2000) observed a reduction in vitamin E content in muscle tissue as a result of feeding pigs with the oil-rich in PUFA, which is evidence of involvement in the synthesis of tocopherol radical. According to Gobert et al. (2009) introduction of supplements in the form of linseed and plant polyphenols (PERP) does not affect the intensification of peroxidation processes in milk, which is also reflected by our study. In the fifth collecting, after 21 days of administration of supplements, the study showed a reduction in the level of MDA in the: FO, LS, FOS and FOO group relative to control collection. The effect of vitamin E on MDA differs between the blood, liver, and mammary gland. Vitamin E supplementation could not prevent the increase in blood MDA at calving, but the significantly lower MDA blood concentrations of supplemented cows in the second week post partum suggests that vitamin E plays a role in recovery from parturition-related oxidative stress (Bouwstra et al. 2008).

Oxidation products are unstable and they tend to react with food constituents, so their detection may not be a valid tool for quality assessment in all cases. After homogenization without pasteurization, natural milk lipase will cause lipolysis of the raw milk, resulting in formation of FFA. Chilliard (1993) confirms that the addition of feed fat may influence the increase in FFA content. Subsequently, FFA will be broken down to aldehydes and ketones (Deeth \& Fitz-Gerald 2006). Free fatty acids also cause damage and deformation of the milk fat globule membrane, which affect the deterioration of the technological properties of cow's milk (Kuczyńska 2001).

Similar results in terms of increasing vitamin A content in cow's milk after using linseeds were obtained in the studies of Reklewska et al. (2000) and Nałęcz-Tarwacka et al. (2008). Additionally, Reklewska et al. (2000) also noted the increase in concentration of $\beta$-carotene. The increase in milk yield in the following groups: LS, FOS and FOO can also influence the increase of $\beta$-carotene content in milk. This dependence is confirmed by research conducted by Nozière et al. (2006). The highest level of $\beta$-carotene was demonstrated in two groups that received linseed. However, the higher level was found in the LO group, and highest concentration of vitamin A in LS. According to Yang \& Tume (1993) $\beta$-carotene to turn into retinol must undergo certain chemical processes. LS supplementation significantly accelerates this process resulting in increasing of both vitamins in milk.

Content of a-tocopherol, one of the most important antioxidants of cow's milk, varies between 13-30 $\mu \mathrm{g} / \mathrm{g}$ fat (Jensen \& Nielsen 1996). In order to increase its level, it can be injected 
intramuscularly (Charmley \& Nicholson 1994), or included directly in cow feed (Charmley et al. 1993). Adding of oilseeds has a similar effect (Focant et al. 1998, Morales et al. 2000, Bell et al. 2006, Nałęcz-Tarwacka et al. 2008). Increase in the concentration of a-tocopherol in the analysed milk samples may be related to the transfer of supplemented tocopherol (fish oil used in the experiment was nutritionally enriched in a-tocopherol) into milk (Charmley \& Nicholson 1994), which could also affect the oxidative stability of milk (Focant et al. 1998). Addition of a-tocopherol to cow feed affects also improves the digestibility and utilization of $\beta$-carotene, probably due to the antioxidant properties of vitamin $E$ (Morales et al. 2000).

It should be note that increase of $\alpha$-tocopherol, $\alpha$-retinol, and $\beta$-carotene content in milk due to use of fat supplements can also be explained by better use of the diet components. TAS enables the determination of total levels of antioxidant compounds (enzymes, antioxidants endo- and exogenous) in the milk in a very short time, and it is also used to monitor individual antioxidant components, as well as the general state of the system to prevent the oxidation process (Puppel et al. 2011). Research Puppel et al. (2012) has shown that levels of TAS were associated with both supplementation and the age of cows.

Summing up, the most favourable changes in the b-carotene content were due to use of linseed of Opal varieties. The content of vitamin A was on the highest level in the milk of cows treated with linseed of Szafir varieties. Formation of $\beta$-carotene in milk after 21 days of supplementation takes place in accordance with the following scheme: $\mathrm{LO}>\mathrm{LS}>\mathrm{FO}>\mathrm{FOO}>\mathrm{FOS}$, and fora-retinol: $\mathrm{LS}>\mathrm{FO}>\mathrm{FOS}>\mathrm{FOO}>\mathrm{LO}$. The concentration of vitamin $\mathrm{E}$ was highest in the milk of cows that received a mixture of fish oil and linseed of Opal variety (FOO $>\mathrm{LS}>\mathrm{LO}>\mathrm{FO}>\mathrm{FOS}$ ).

Despite the fact that the values determined in the fat-soluble vitamins were at a lower level in FOS compared with other groups, the highest level of TAS was obtained in this particular group. This indicates that the determination of antioxidants only on the basis of the level of fat soluble vitamins is inadequate, and therefore all antioxidant components should be taken into account to correctly determine the level of total TAS. Research has confirmed that in nutritional experiments, not only the form, quantity or physical form of linseed, but also the variety should be taken into consideration.

\section{References:}

Allred SL, Dhiman TR, Brennand CP, Khanal RC, McMahon DJ, Luchini ND (2006) Milk and Cheese from Cows Fed Calcium Salts of Palm and Fish Oil Alone or in Combination with Soybean Products. J Dairy Sci 89, 234-248

AOAC (1990) Official Methods of Analysis of the Association of Official Analytical Chemists, AOAC Intl, Gaithersburg, USA

Bell JA, Griinari JM, Kennelly JJ (2006) Effect of Safflower Oil, Flaxseed Oil, Monensin, and Vitamin E on Concentration of Conjugated Linoleic Acid in Bovine Milk Fat. J Dairy Sci 89, 733-748

Bharathan M, Schingoethe DJ, Hippen AR, Kalscheur KF, Gibson ML, Karges K (2008) Conjugated Linoleic Acid Increases in Milk from Cows fed Condensed Corn Distillers Solubles and Fish Oil. J Dairy Sci 91, 2796-2807

Bobe G, Lindberg GL, Reutzel LF, Hanigan MD (2009) Effects of lipid supplementation on the yield and composition of milk from cows with different beta-lactoglobulin phenotypes. J Dairy Sci 92, 197-203

Bouwstra RJ, Goselink RMA, Dobbelaar P, Nielen M, Newbold JR, van Werven T (2008) The Relationship Between Oxidative Damage and Vitamin E Concentration in Blood, Milk, and Liver Tissue from Vitamin E Supplemented and Nonsupplemented Periparturient Heifers. J Dairy Sci 91, 977-987 
Charmley E, Nicholson JWG (1994) Influence of dietary fat source on oxidative stability and fatty acid composition of milk from cows receiving a low or high level of dietary vitamin E. Can J Anim Sci 74, 657-664

Charmley E, Nicholson JWG, Zee JA (1993) Effect of supplemental vitamin E and selenium in the diet on vitamin $E$ and selenium levels and control of oxidized flavor in milk from Holstein cows. Can J Anim Sci 73, 453-457

Chen JJ, Petersen DR, Schenker S, Henderson GI (2000) Formation of Malonedialdehyde Adducts in Livers of Rats Exposed to Ethanol: Role in Ethanol-Mediated Inhibition of Cytochrome c Oxidase. Alcohol Clin Exp Res 24, 544-552

Chilliard Y (1993) Dietary Fat and Adipose Tissue Metabolism in Ruminants, Pigs, and Rodents: A Review. J Dairy Sci 76, 3897-3931

Chilliard Y, Martin C, Rouel J, Doreau M (2009) Milk fatty acids in dairy cows fed whole crude linseed, extruded linseed, or linseed oil, and their relationship with methane output. J Dairy Sci 92, 5199-5211

Deeth HC, Fitz-Gerald CH (2006) Lipolytic Enzymes and Hydrolytic Rancidity. Adv Dairy Chem Vol 2 Lipids, 481-556

DePeters EJ, Taylor SJ (1985) Effects of Feeding Corn or Barley on Composition of Milk and Diet Digestibility. J Dairy Sci 68, 2027-2032

DePeters EJ, Cant JP (1992) Nutritional Factors Influencing the Nitrogen Composition of Bovine Milk: A Review. J Dairy Sci 75, 2043-2070

Doreau M, Chilliard Y, Relquin H, Demeyer DI (1999) Manipulation of milk fat in dairy cows. In: Garnsworthy PC, Wiseman J (eds.) Recent Advances in Animal Nutrition. Nottingham University Press, Nottingham, UK, 81-109

Flowers G, Ibrahim SA, AbuGhazaleh AA (2008) Milk Fatty Acid Composition of Grazing Dairy Cows When Supplemented with Linseed Oil. J Dairy Sci 91, 722-730

Focant M, Mignolet E, Marique M, Clabots F, Breyne T, Dalemans D, Larondelle Y (1998) The Effect of Vitamin E Supplementation of Cow Diets Containing Rapeseed and Linseed on the Prevention of Milk Fat Oxidation. J Dairy Sci 81, 1095-1101

Gladine C, Morand C, Rock E, Bauchart D, Durand D (2007) Plant extracts rich in polyphenols (PERP) are efficient antioxidants to prevent lipoperoxidation in plasma lipids from animals fed $n-3$ PUFA supplemented diets. Anim Feed Sci Technol 136, 281-296

Gobert M, Martin B, Ferlay A, Chilliard Y, Graulet B, Pradel P, Bauchart D, Durand D (2009) Plant polyphenols associated with vitamin $E$ can reduce plasma lipoperoxidation in dairy cows given $n-3$ polyunsaturated fatty acid. J Dairy Sci 92, 6095-6104

Gonzalez MJ, Schemme RA, Dugan Jr LR, Gray Jl, Welsch CW (1993) Dietary fish oil inhibits human breast carcinoma growth: A function of increased lipid peroxidation. Lipids 28, 827-832

Jensen SK, Nielsen KN (1996) Tocopherols, retinol, beta-carotene and fatty acids in fatglobule membrane and fat globule core in cows' milk. J Dairy Res 63, 565-574

Kamal-Eldin A, Appelquist LA (1996) The chemistry and antioxidant properties of tocopherols and tocotrienols. Lipids 31, 671-701

King RL (1967) Vitamin E in the dairy ration and oxidized flavor in milk. Proc Maryland Nutr Conf Feed Manuf, College Park MD, 13

Kuczyńska B (2001) Study on factors affecting fat changes in cow's and goat's milk. PhD thesis, SGGW, Warsaw, Poland

Kramer JKG, Parodi PW, Jensen RG, Mossoba MM, Yurawecz MP, Adlof RO (1998) Rumenic acid: A proposed common name for the major conjugated linoleic acid isomer found in natural products. Lipids 33, 835

Sol Morales M, Palmquist DL, Weiss WP (2000) Milk Fat Composition of Holstein and Jersey Cows with Control or Depleted Copper Status and Fed Whole Soybeans or Tallow. J Dairy Sci 83, 2112-2119

Mroczek J (1967) [Researches on the sustainability of fat obtained from pig lard]. PhD thesis. Warsaw University of Life Sciences, Warsaw, Poland [in Polish] 
Nałęcz-Tarwacka T, Grodzki H, Kuczyńska B (2008) Usefulness of linseeds for the modification of fat fraction components in cow milk. Medycyna Weterynaryjna 64, 85-87

Naziroglu M, Karaoglu A, Aksoy AO (2004) Selenium and high dose vitamin E administration protects cisplatininduced oxidative damage to renal, liver and lens tissues in rats. Toxicology 195, 221-230

Nelson KAS, Martini S (2009) Increasing omega fatty acid content in cow's milk through diet manipulation: Effect on milk flavor. J Dairy Sci 92, 1378-1386

Nozière P, Graulet B, Lucas A, Martin P, Grolier P, Doreau M (2006) Carotenoids for ruminants: From forages to dairy products. Anim Feed Sci Technol 131, 418-450

O'Grady MN, Monahan FJ, Fallon RJ, Allen P (2001) Effects of dietary supplementation with vitamin E and organic selenium on the oxidative stability of beef. J Anim Sci 79, 2827-2834

Palozza P, Calviello G, Maggiano N, Lanza P, Ranelletti FO, Bartoli GM (2000) Beta-carotene antagonizes the effects of eicosapentaenoic acid on cell growth and lipid peroxidation in WiDr adenocarcinoma cells. Free Radic Biol Med 28, 228-234

Puppel K (2011) The influence of fish oil and linseed supplementation on the fat and the protein fraction content of cow's milk. PhD thesis, SGGW Warsaw, Poland

Puppel K, Nałęcz-Tarwacka T, Kuczyńska B, Gołębiewski M, Kordyasz M, Grodzki H (2012) The age of cows as a factor shaping the antioxidant level during a nutritional experiment with fish oil and linseed supplementation for increasing the antioxidant value of milk. J Sci Food Agric 92, 2494-2499

Reklewska B, Oprządek A, Reklewski Z, Panicke L, Kuczyńska B, Oprządek J (2002) Alternative for modifying the fatty acid composition and decreasing the cholesterol level in milk of cows. Livest Prod Sci 76, 235-243

Rice-Evans CA, Sampson J, Bramley PM, Holloway DE (1997) Why Do We Expect Carotenoids to be Antioxidants in vivo? Free Radic Res 26, 381-398

Sawosz E (2000) Influence of diet enriched in PUFA, a-tokoferol and sodium ascorbates on PUFA in muscle tissiu of growing rat and pigs. Treaties and Monographs, Publications of Warsaw Agricultural University, Poland

Sympoura F, Cornu A, Tournayre P, Massouras T, Berdagué JL, Martin B (2009) Odor compounds in cheese made from the milk of cows supplemented with extruded linseed and a-tocopherol. J Dairy Sci 92, 3040-3048

Yang A, Tume RK (1993) A comparison of beta-carotene-splitting activity isolated from intestinal mucosa of pasture-grazed sheep, goats and cattle. Biochem Mol Biol Int 30, 209-217 